\title{
The effect on digestion in the rumen of a gradual increase in the content of fatty acids in the diet of sheep
}

\author{
By J. W. CZERKAWSKI \\ Hannah Dairy Research Institute, Ayr \\ (Received I8 March 1966-Accepted I8 fuly 1966)
}

\begin{abstract}
I. Two sheep were given cubed rations in which the fatty acid content was increased by about $12 \mathrm{~g} /$ day at the end of each week, until the daily intake became $74 \mathrm{~g}$. 2. The apparent digestibility of the crude lipid increased with the increased intake, but there was no tendency for the digestibility of the fatty acids to increase or decrease regularly. 3. Comparison of faecal losses during the final periods, when a maximum amount of lipid was given, with the losses during the initial control periods showed that the excretion of dry matter, crude lipid and cellulose increased. The excretion of crude protein was unchanged and that of lipid- and cellulose-free dry matter decreased. There was a reduction in the production of methane of $17 \mathrm{kcal} / 100 \mathrm{kcal}$ of additional fatty acids in the diet. 4 . The concentration of the $\mathrm{C}_{18}$ unsaturated acids in the rumen liquor reached a maximum during the ist week on the diet containing the maximum amount of added fatty acids. The shape of the curves was consistent with rapid hydrogenation of linolenic acid. 'The concentration of stearic acid in the rumen liquor reached a maximum when the dietary acids increased to only $50 \%$ of their maximum value.
\end{abstract}

It was shown by Czerkawski, Blaxter $\&$ Wainman (r966a) that infusion of unsaturated fatty acids into the rumen of sheep led to a marked lowering in the production of methane. The same authors ( $1966 b$ ) found later that the production of methane could be lowered also by incorporating the unsaturated, and, to a somewhat smaller extent, the saturated long-chain fatty acids in the diet. Most of these experiments did not last longer than 4 weeks, and no attempt was made to increase the fatty acid content of the diet gradually.

The turnover of microbial population in the rumen is relatively large, and it was judged unlikely, at least on the basis of previous work (Czerkawski et al. 1966a) that it would take longer than 3 weeks on a given regimen to establish an equilibrium. It was noticed by Czerkawski et al. (1966a) that methane production began to fall at once when $40-80 \mathrm{~g}$ of linseed oil fatty acids were infused daily into the rumen of sheep, and that it reached a steady low value after 3-8 days of infusion, the length of time varying with the amount infused. After infusion was stopped it took somewhat longer for the methane production to return to the normal value.

The object of the experiment now described was to increase the fatty acid content of the diet in suitable steps, and to examine the effect on digestion in the rumen. It was felt that 7 days on any one transition diet would be ample, because each contemplated increment would be less than $20 \mathrm{~g} /$ day, an amount which had previously been found to give only a very small reduction in methane production and which resulted in a steady new value of daily methane production after only $2-3$ days. 


\section{EXPERIMENTAL}

Animals. Two castrated male sheep with permanent rumen cannulas were used and kept in metabolism cages throughout except for 2-day periods at the beginning and end of the experiment, when they were placed in respiration chambers (Wainman \& Blaxter, $195^{8}$ ) for methane production to be measured.

Rations. The basal concentrate diet was in the form of cubes which had the following composition in $\mathrm{kg}$ : barley meal $40^{\circ} 0$; oat husk $20^{\circ} 0$; oatmeal $20^{\circ} 0$; sugar-beet pulp $5 \cdot 0$; dry grass meal $72 \cdot 6 ; \mathrm{NaCl}_{\mathrm{I}} \cdot 5 ; \mathrm{CaHPO}_{4} 0 \cdot 75 ; \mathrm{MgO}_{0} \cdot \mathrm{I}_{5} ;$ total $\mathrm{I} 60 \cdot 0 \mathrm{~kg}$. Of this mixture $80 \mathrm{~kg}$ were cubed to give the control diet. The remaining $80 \mathrm{~kg}$ were mixed with $8.0 \mathrm{~kg}$ linseed oil fatty acids (British Drug Houses Ltd, Poole, Dorset; linoleic acid so-called), and then made into 'fatty acid' cubes.

The sheep were given $900 \mathrm{~g}$ control ration or $990 \mathrm{~g}$ fatty acid cubes daily in two equal meals. They were also given I50 $\mathrm{g}$ dried grass with the evening meal only. These constituted regimens $\mathrm{A}$ and $\mathrm{F}$ respectively; the intermediate rations $(\mathrm{B}-\mathrm{E})$, were prepared by mixing the control cubes and the fatty acid cubes in suitable proportions. The crude lipid and fatty acid composition of all the rations is summarized in Table $\mathbf{I}$.

Table I. Lipid content of the rations

\begin{tabular}{|c|c|c|c|c|c|}
\hline \multirow[b]{2}{*}{ Diet } & \multirow{2}{*}{$\begin{array}{l}\text { Nominal } \\
\text { amount } \\
\text { of oil } \\
\text { added } \\
\text { (g/day) }\end{array}$} & \multicolumn{2}{|c|}{$\begin{array}{l}\text { Crude lipid content } \\
\text { as analysed }\end{array}$} & \multicolumn{2}{|c|}{$\begin{array}{l}\text { Fatty acid content } \\
\text { as analysed }\end{array}$} \\
\hline & & g/day* & Increment & $\mathrm{g} /$ day* & Increment \\
\hline A & o & $40 \cdot 2$ & - & $11 \cdot 7$ & - \\
\hline B & I 8 & $5^{8 \cdot 5}$ & $18 \cdot 3$ & $24^{\circ} I$ & $12 \cdot 4$ \\
\hline $\mathrm{C}$ & 36 & $76 \cdot 7$ & $36 \cdot 5$ & $36 \cdot 5$ & $24 \cdot 8$ \\
\hline D & 54 & 94.9 & $54 \cdot 7$ & 490 & $37 \cdot 3$ \\
\hline $\mathrm{E}$ & 72 & II3.I & $72 \cdot 9$ & 614 & $49 \cdot 7$ \\
\hline $\mathrm{F}$ & 90 & I3I.4 & $91 \cdot 2$ & 73.9 & $62 \cdot 2 \dagger$ \\
\hline
\end{tabular}

* Includes the lipids derived from the cube rations and from the dry-grass supplement.

+ The linseed oil fatty acid perparation contained $68.9 \%$ fatty acids, of which $63.5 \%$ was linolenic acid. This proportion of fatty acids would give normally $61.9 \mathrm{~g} /$ day increment in ration $F$ compared with the $62 \cdot 2 \mathrm{~g}$ found.

Plan of experiment. The sheep were given control ration A for 3 weeks. They then received ration $B$ each day throughout the $4^{\text {th }}$ week, ration $C$ in the $5^{\text {th, ration } D \text { in }}$ the 6 th, ration $E$ in the $7^{\text {th }}$ and ration $F$ in the 8 th, 9 th and roth weeks.

During the last 4 days of the period on each diet the faeces excreted by the sheep were collected and bulked for analysis. On the last day of the various periods two samples of rumen contents (about $50 \mathrm{ml}$ each) were withdrawn, one $2 \mathrm{~h}$ after the morning feed and one just before the evening feed. The samples were withdrawn by means of a probe made of perspex. A tube closed at one end was fitted into a shorter tube (outer diam. $1.6 \mathrm{~cm}$ ). Longitudinal slits $15 \mathrm{~cm}$ long and whose width was equivalent to $\frac{1}{3}$ of the circumference were cut in each tube. The low end of the slits was about $2 \mathrm{~cm}$ from the closed end of the tubes. The probe was introduced into the rumen in the closed position (slits at $x 80^{\circ}$ to each other). It was opened by turning the outer tube (slits coincident), gentle suction was applied at the top of the inner tube, and the 
probe was closed by turning the outer tube. The probe was withdrawn and the contents, representative of about $15 \mathrm{~cm}$ of the vertical cross-section of the rumen, were transferred to a flask. This procedure gave between ro and $15 \mathrm{ml}$ of contents and was repeated four times during each sampling to give about $50 \mathrm{ml}$ in all. The morning and evening samples from each sheep were weighed and equal amounts were pooled and analysed.

Analyses. The total lipids in the rumen contents were extracted by the method of Folch, Lees \& Stanley (1957); the faecal lipids were extracted in the same way, but the material was previously treated with hot $2 \mathrm{~N}-\mathrm{HCl}$ to convert the soaps into fatty acids. The methyl esters of the total fatty acids in the various samples were prepared and isolated by the method of Kates (1964). They were subsequently analysed on the Pye argon gas-liquid chromatograph with $\mathrm{r} \%$ polyethylene glycol adipate, and sometimes Apiezon $\mathrm{L}$, as the stationary phase on chromosorb $\mathrm{W}$ at $197^{\circ}$. The cis- and trans-isomers of octadecenoic acids were sufficiently resolved on Apiezon L columns to give a fair estimate of their relative distribution. Sometimes it was necessary to separate these components on thin-layer plates of silicic acid impregnated with $10 \%$ $(\mathrm{w} / \mathrm{v})$ silver nitrate before gas-liquid chromotography. No attempt was made to determine the position of the double bond in the octadecenoic acids. The feed lipids were analysed in the same way.

Cellulose was estimated by the method of Crampton \& Maynard (1938), and other routine analyses, such as those for nitrogen, carbon and calorific values, were as described by Armstrong, Blaxter \& Graham (1957).

There was usually good agreement between the fatty acid contents of the samples obtained from the two sheep. For instance, the average deviation from the means of the results for the major component fatty acids (palmitic, stearic, monoenoic $\mathrm{C}_{18}$, linoleic) from the rumen and the faeces of the two sheep was usually less than $5 \%$. The difference between the duplicates was greater with the minor components. The results reported in this paper are expressed as means for the two sheep.

\section{RESULTS}

\section{Intake and excretion of lipids}

Crude lipid and total fatty acids. It is shown in Table $\mathrm{I}$ that the intake of crude lipid during the control period was $4 \circ \mathrm{g} /$ day and that during the final period on ration $\mathrm{F}$ it reached I $3 \mathrm{I} g$ /day. The excretion of crude lipid was $23 \mathrm{~g}$ /day during the control period and increased to about $4^{\mathrm{I}} \mathrm{g} /$ day during the period on ration $\mathrm{F}$, i.e. the amount excreted was doubled when the intake was increased three times. The intake of fatty acids was increased gradually from $12 \mathrm{~g} /$ day to a maximum value of $74 \mathrm{~g} /$ day, and this resulted in an increase in excretion of fatty acids from $\mathrm{I} \cdot 6 \mathrm{~g} /$ day to about $8 \mathrm{~g} /$ day.

These results, expressed as apparent digestibilities, are summarized in Table 2. The digestibility of the crude lipid increased significantly during the gradual increase in the lipid content of the diet. On the other hand, the digestibility of the non-fatty acid portion of crude lipid varied from about $24.5 \%$ on ration $A$ to almost $4 \mathrm{I} \%$ during the $3^{\text {rd }}$ week on ration $F$, most of the intermediate values being about $3 I \%$. The 
increase in digestibility of crude lipid can be explained by the inclusion of increasing proportions of the more digestible fatty acids.

Excretion of individual fatty acids. It was convenient to show the relation between the excretion of the individual acids and their daily intake by calculating the ratio of excretion to intake. Clearly, this ratio subtracted from unity and multiplied by 100 would give the corresponding apparent digestibility. These ratios are plotted in Fig. I. It should be noted that small values such as were found with the polyunsaturated fatty acids mean that only between 0.5 and $5 \%$ of the ingested acid was excreted in the faeces, a large proportion of this being of endogenous origin. The ratio was greater than $\mathrm{I}$ with stearic acid (Fig. I $a$ ) which means that the amounts of stearic acid excreted were greater than the amounts ingested. This was to be expected, because stearic acid is the end-product of hydrogenation of the unsaturated $\mathrm{C}_{18}$ acids. The

Table 2. Apparent digestibility (\%) of the lipids by two sheep

\begin{tabular}{|c|c|c|c|}
\hline Diet & Crude lipid & Fatty acids & $\begin{array}{l}\text { Non-fatty } \\
\text { acid lipid }\end{array}$ \\
\hline A & $42 \cdot I$ & $86 \cdot 8$ & 24.5 \\
\hline B & 55.9 & $91 \cdot 9$ & 30.8 \\
\hline C & 56.0 & 85.0 & $3 \mathrm{I} \cdot 5$ \\
\hline D & - & - & - \\
\hline $\mathrm{E}$ & $60 \cdot 6$ & $74 \cdot 7$ & $32 \cdot 0$ \\
\hline F (Ist week) & $56 \cdot 6$ & 87.5 & I9.0 \\
\hline F (2nd week) & $64 \cdot 0$ & $89^{\circ} 4$ & $3 I \cdot 5$ \\
\hline F ( 3 rd week) & $68 \cdot 6$ & 90.3 & 40.6 \\
\hline
\end{tabular}

extent of excretion of palmitic acid is also shown in Fig. $\mathrm{a} a$. The ratios of oleic, linoleic and linolenic acids are plotted in Fig. $\mathrm{I} b$. The ratios dropped consistently at first when the dietary acids were increased, but they then increased, particularly with oleic acid. The ratios dropped again when the diet richest in fat (ration F) was given, indicating that the animals were becoming adapted to the new conditions.

The ability to deal with an influx of additional fatty acids is particularly noticeable with linolenic acid. When the intake of this acid was $4 \mathrm{~g} /$ day (diet $\mathrm{A}$ ), about $2 \%$ of the acid was excreted in the faeces; when the intake was increased to $43 \mathrm{~g} /$ day, only $0.5 \%$ of it was excreted. In other words the excretion of linolenic acid was only doubled when the intake was increased ten times.

It was of interest to inquire into the nature of the $\mathrm{C}_{18}$ monoenoic acids in faeces. The dietary monoenoic acid was almost wholly in the cis-form. During the control period (ration A) only $17 \%$ of the $\mathrm{C}_{18}$ monoenoic acid in the faeces was in the transform; the remainder occurred as oleic acid, the major portion of which was probably of endogenous origin. When the monoenoic acids in the faeces from the final period

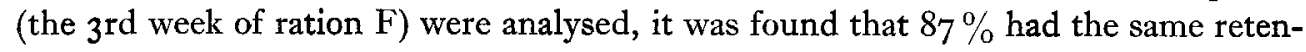
tion volume on Apiezon $\mathrm{L}$ as elaidic acid. This is consistent with previous findings (Czerkawski \& Blaxter, 1965) that a trans-monoenoic acid might be an intermediate in the hydrogenation of polyenoic acids in the rumen.

The bacterial fatty acids, which include the branched-chain $\mathrm{C}_{15}$ to $\mathrm{C}_{18}$ acids, and the acids with odd numbers of carbon atoms $\left(\mathrm{C}_{13}\right.$ to $\left.\mathrm{C}_{19}\right)$, were found in the rumen 
and in the faeces but occurred in negligible amounts in the diet. They would be formed mainly in the rumen, and their excretion increased from $160 \mathrm{mg} /$ day during the control period on ration $A$ to about $400 \mathrm{mg} /$ day on ration $E$. The excretion then began to fall and finally became $260 \mathrm{mg} /$ day during the 3 rd week of ration $F$. The increase was due mainly to an increase in acids with an odd number of carbon atoms, particularly $\mathrm{C}_{\mathbf{1 9}}$.
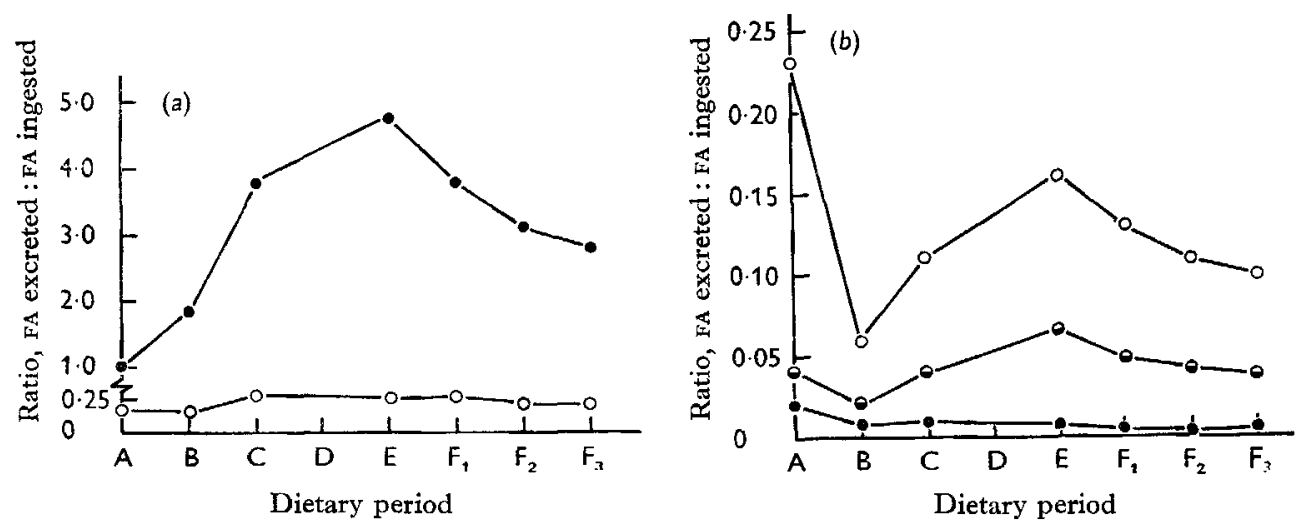

Fig. 1. Variation of the ratio of the amount of fatty acid excreted in the faeces to the amount of fatty acid (FA) given in the diet of two sheep. $A$ is the last week on the control diet, $B-E$ are the weeks on the diets with increasing fatty acid content (see p. 834), and $F_{1}, F_{2}, F_{8}$ are the rst, 2nd and 3 rd weeks on the diet $\mathrm{F}$ which had the maximum fatty acid content. $(a)-1$ acid; $O-O$, palmitic acid; (b) $\bigcirc-0$, octadecenoic acid; $\ominus-\odot$, linoleic acid; $-\odot$, linolenic acid.

Table 3. Intake and faecal excretion of various components by two sheep

\begin{tabular}{|c|c|c|c|c|c|}
\hline $\begin{array}{c}\text { Dietary } \\
\text { period }\end{array}$ & $\begin{array}{c}\text { Dry } \\
\text { matter }\end{array}$ & $\begin{array}{l}\text { Crude } \\
\text { protein }\end{array}$ & $\begin{array}{l}\text { Crude } \\
\text { lipid }\end{array}$ & Cellulose & $\begin{array}{l}\text { Lipid-and } \\
\text { cellulose-free } \\
\text { dry matter }\end{array}$ \\
\hline & \multicolumn{5}{|c|}{ Daily intake (g) } \\
\hline \multirow[t]{2}{*}{$A-F$} & $788-882$ & IOI & $40-131$ & 267 & 483 \\
\hline & \multicolumn{5}{|c|}{ Daily excretion (g) } \\
\hline A & $308 \cdot 2$ & $34^{\circ} \circ$ & $23 \cdot 3$ & II $8 \cdot 2$ & I $66 \cdot 7$ \\
\hline B & $312 \cdot 0$ & 344 & $25 \cdot 8$ & $120 \cdot 6$ & $165 \cdot 0$ \\
\hline $\mathrm{C}$ & $328 \cdot 0$ & $35 \%$ & 33.7 & 130.0 & $164 \cdot 3$ \\
\hline $\mathrm{D}$ & $311 \cdot 5$ & $32 \cdot 5$ & $\left(39^{\circ} 0\right)^{*}$ & $121 \cdot 4$ & $(140.3)^{*}$ \\
\hline $\mathrm{E}$ & $314 \cdot 2$ & 30.8 & $44 \cdot 5$ & $124 \% 7$ & $145^{\circ} \mathrm{O}$ \\
\hline F (Ist week) & $356 \cdot 7$ & $35 \cdot 3$ & $57^{\cdot I}$ & $146 \cdot 9$ & $152 \cdot 7$ \\
\hline F (2nd week) & $335^{\circ} 5$ & $34 \cdot 6$ & $47 \cdot 4$ & $\mathbf{1} 42 \cdot 8$ & $145^{\circ} 3$ \\
\hline F (3rd week) & $332 \cdot I$ & $33^{2} 2$ & $4 I \cdot 2$ & 140.5 & 150.4 \\
\hline Changet & +23.9 & -0.8 & +179 & $+22 \cdot 3$ & $-16 \cdot 3$ \\
\hline
\end{tabular}

Intake and excretion of non-lipid components and loss of energy as methane

Table 3 shows the daily intakes and faecal excretions of dry matter, crude protein, crude lipid and cellulose, and of the lipid- and cellulose-free dry matter.

The increased loss of dry matter in faeces $(23.9 \mathrm{~g})$ was partly due to increased faecal lipid content $(\mathrm{I} 7 \cdot 9 \mathrm{~g})$. There was virtually no change in the loss of crude protein. The 
excretion of cellulose was increased $(22 \cdot 3 \mathrm{~g})$; this was more than was found previously during infusion of similar fatty acids. The last column of Table 3 shows that the excretion of the lipid- and cellulose-free dry matter was decreased ( $16.3 \mathrm{~g} /$ day).

The mean daily production of methane fell from 35.51 . during the control period to $23.5 \mathrm{l}$. during the last week on ration $\mathrm{F}$, when the sheep were receiving some $74 \mathrm{~g}$ fatty acids/day. Thus there was a reduction of more than $30 \%$ in the production of methane, whereas the digestion of cellulose was decreased by only about $14 \%$. Expressed in a different way, this means that roo kcal of additional linseed oil fatty acids produced a decrease in the formation of methane equivalent to $17 \mathrm{kcal}$. Previous experiments have shown that continuous infusion of these acids gave a decrease of $16 \mathrm{kcal}$ methane $/ 100 \mathrm{kcal}$ fatty acids, and incorporation into concentrate cubes that were given twice daily but without gradual adaptation gave a drop of $28 \mathrm{kcal}$ methane/ $100 \mathrm{kcal}$ fatty acids (Czerkawski et al. I966b).
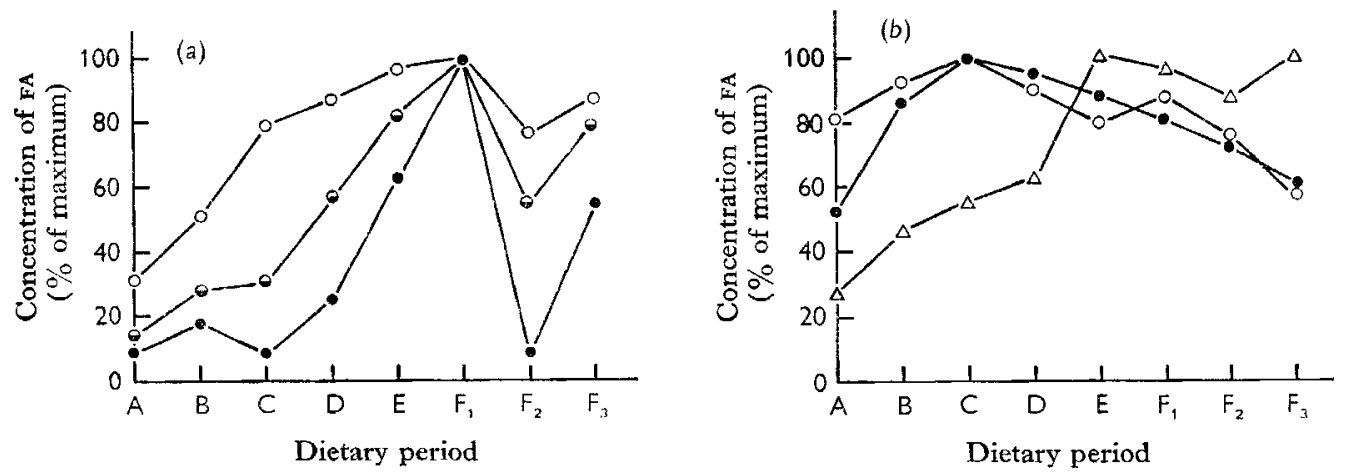

Fig. 2. Concentration of fatty acids (FA) in the rumen of two sheep, expressed as a percentage of the maximum value for any given acid. A represents the last week of the control period, $\mathrm{B}-\mathrm{E}$ are the weeks on the diets with increasing fatty acid content (see p. 834), and $F_{1}, F_{2}, F_{3}$ are the Ist, and and 3 rd weeks on diet $F$, which had the maximum fatty acid content. (a) $\bigcirc-\bigcirc$, octadecenoic acid; $\bullet-\odot$, linoleic acid; $\bullet-$, linolenic acid; (b) $\bigcirc-0$, palmitic acid; - - stearic acid; $\triangle-\Delta$, bacterial fatty acids (sum of branched-chain and odd carbon number fatty acids).

\section{Fatty acids in the rumen}

It has already been shown in previous sections that the addition of fatty acids to the diet produced little change in the overall digestibility of the acids, and that the ruminal flora is still apparently capable of hydrogenating the unsaturated acids.

The more immediate fate of the dietary fatty acids was investigated by determining their concentration in the rumen. Table 4 gives the amounts of individual acids consumed per day, and the concentration in the rumen at the end of each period. The concentrations, expressed as a percentage of the maximum value for any given acid, are plotted in Fig. 2.

The curves for the three unsaturated $\mathrm{C}_{18}$ acids (Fig. $2 a$ ) are similar; they all show that a maximum value occurred at the end of the rst week on ration $F$, i.e. when the dietary fatty acids had reached their maximum value. According to these curves the results for linolenic and linoleic acids were more closely related to each other than to the results for the monoenoic $\mathrm{C}_{18}$ acids. The rapidity with which the concentration of 
the three acids approached the maximum value and began to fall depended very much on the degree of unsaturation of the acids. It was twice as great for linoleic and four times as great for linolenic as for monoenoic acid. This probably reflects the rapidity with which these acids are hydrogenated. Linolenic acid is hydrogenated rapidly (Shorland, Weenink, Johns \& McDonald, I957; Lough \& Garton, 1958) so it would not be expected to accumulate until the influx reached a certain saturation point.

Table 4. Intakes of individual fatty acids by the two sheep and their concentration in the rumen

\begin{tabular}{|c|c|c|c|c|c|c|}
\hline $\begin{array}{c}\text { Dietary } \\
\text { period }\end{array}$ & I6:0* & I 8:0 & I 8: I & I 8:2 & I $8: 3$ & Otherst \\
\hline \multicolumn{7}{|c|}{ Daily intake (g) } \\
\hline A & $\mathrm{I} \cdot 6$ & 0.3 & $2 \cdot 3$ & $2 \cdot 9$ & $3 \cdot 7$ & $O \cdot I$ \\
\hline B & $2 \cdot 2$ & 0.5 & $4 \cdot 3$ & 4.7 & II. 6 & $O \cdot I$ \\
\hline C & $2 \cdot 8$ & 0.7 & $6 \cdot 3$ & $6 \cdot 5$ & $19 \cdot 4$ & $0 \cdot 1$ \\
\hline $\mathrm{D}$ & 3.4 & $I \cdot 0$ & $8 \cdot 4$ & $8 \cdot 3$ & $27 \cdot 3$ & 0.0 \\
\hline $\mathbf{E}$ & 4.0 & $I \cdot 2$ & 10.4 & IO' I & $35^{\cdot 2}$ & 0.0 \\
\hline F (3 weeks) & $4 \cdot 5$ & $I \cdot 4$ & $12 \cdot 4$ & $\mathrm{II} \cdot 9$ & $43^{\cdot I}$ & 0.0 \\
\hline \multicolumn{7}{|c|}{ Concentration in the rumen contents $(\mathrm{g} / 5 \mathrm{l}$ ) } \\
\hline$A$ & $2 \cdot 7$ & $7 \cdot 2$ & $2 \cdot 5$ & 0.5 & 0.2 & 0.6 \\
\hline B & $3 \cdot 1$ & I $1 \cdot 6$ & $3 \cdot 7$ & $I \cdot 0$ & 0.4 & $\mathrm{I} \cdot \mathrm{O}$ \\
\hline C & $3 \cdot 3$ & 13.5 & $5 \cdot 7$ & $\mathbf{I} \cdot \mathbf{I}$ & 0.2 & $I \cdot 2$ \\
\hline D & $3 \cdot 0$ & $12 \cdot 8$ & $6 \cdot 3$ & $2 \cdot 1$ & 0.6 & $I \cdot 3$ \\
\hline $\mathbf{E}$ & $2 \cdot 6$ & I I 9 & $7 \cdot I$ & $3 \cdot 0$ & $I \cdot 4$ & $2 \cdot I$ \\
\hline F (Ist week) & 2.9 & II. & $7 \cdot 2$ & $3 \cdot 6$ & $2 \cdot 3$ & $2 \cdot 0$ \\
\hline F (2nd week) & 2.5 & 9.9 & $5 \cdot 6$ & $2 \cdot 0$ & 0.2 & $x \cdot 8$ \\
\hline F (3rd week) & I.9 & $7 \cdot 7$ & 6.4 & $2 \cdot 9$ & $x \cdot 3$ & $2 \cdot 2$ \\
\hline
\end{tabular}

* The first figure refers to the number of carbon atoms in the chain; the figure after the colon refers to the number of double bonds.

$\uparrow$ Sum of branched-chain and odd carbon number fatty acids, possibly of bacterial origin.

Table 5. Composition of octadecenoic acids in the rumen of two sheep

\begin{tabular}{|c|c|c|}
\hline \multirow{2}{*}{$\begin{array}{l}\text { Dietary } \\
\text { period }\end{array}$} & \multicolumn{2}{|c|}{$\begin{array}{l}\text { Concentration in the rumen } \\
\qquad(\mathrm{g} / 5 \mathrm{l})\end{array}$} \\
\hline & Oleic acid & Elaidic acid* \\
\hline$A$ (control) & $1 \cdot 0(40) t$ & I.5 $(60)$ \\
\hline $\mathrm{E}$ & $I \cdot 9(27)$ & $5 \cdot 3(73)$ \\
\hline F (3rd week) & $0.8(14)$ & $5 \cdot 5(86)$ \\
\hline
\end{tabular}

* Identified tentatively as described by Czerkawski \& Blaxter (I965).

$\dagger$ Figures in parentheses are percentages of the total octadecenoic acid.

The curves for the concentrations of the two unsaturated acids (Fig. $2 b$ ) differ considerably from those of the unsaturated acids. Both have a maximum value at the end of period $C$, i.e. when the amount of fatty acid in the diet had been raised to only about half its maximum value. The concentration of these acids in the rumen then began to fall slowly at first (up to the ist week of ration F) and then more rapidly.

The curve relating the concentration of fatty acids of bacterial origin to the dietary period differs from all the other curves. The concentration reached the maximum value at the end of period $\mathrm{E}$ and then remained approximately constant. 
There was an accumulation of trans-octadecenoic acid in the rumen when the amount of linolenic acid in the diet was increased (Table 5). The proportion of oleic acid in the rumen during the control period was smaller (40\% of monoenoic acids) than in the faeces during the same period $(83 \%)$. During the final experimental

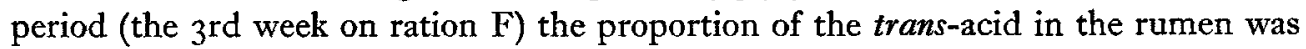
nearly the same as in the faeces ( 86 and $87 \%$ of octadecenoic acids).

\section{DISCUSSION}

The digestibility of stearic acid incorporated in the diet might be smaller than that of stearic acid newly formed in the rumen. When small amounts of stearic acid (20-39 $\mathrm{g} /$ day) were incorporated into diets of sheep, between 80 and $90 \%$ of this acid was apparently digested (Czerkawski, unpublished results). In one experiment the digestibility dropped to about $60 \%$ when the amount of stearic acid was increased to $50-60$ $\mathrm{g} /$ day. The digestibility of stearic acid appears to be low in omnivorous animals, where the value rarely exceeds $50 \%$ (Hilditch \& Williams, 1964), except perhaps when it is part of a mixed triglyceride. Stearic acid has a high melting point $\left(69^{\circ}\right)$ and even its sodium salt is only sparingly soluble in water. Thus it would tend to remain in a relatively coarse form and it might not be readily accessible to micro-organisms.

During the present experiment, when the sheep were on the 'fatty acid' diet, the intake of stearic acid was $1 \cdot 4 \mathrm{~g}$ /day and the intake of unsaturated $\mathrm{C}_{18}$ acids was 67.4 $\mathrm{g} /$ day. If the latter acids were fully hydrogenated in the rumen and if all the acids passed without loss into the abomasum, the abomasal intake would be $68.8 \mathrm{~g}$ of stearic acid/day. Ulyatt, Czerkawski \& Blaxter (1966) have shown that $85 \%$ of unsaturated fatty acids are hydrogenated in the rumen, and if one assumes that these results can be applied here then the total amount of stearic acid leaving the rumen might be $58.5 \mathrm{~g}$ /day. During the last week on ration F the sheep excreted $7 \cdot 2 \mathrm{~g}$ of fatty acids per day and $56 \%$ of this was stearic acid $(4 \circ \mathrm{g})$. Therefore the apparent digestibility of the combined dietary and newly formed stearic acid was $93 \%$. This calculation ignores a possible further hydrogenation in the caecum (Ward, Scott \& Dawson, 1964).

There is evidence of lipolytic activity in the rumen (Garton, Hobson \& Lough, I958; Garton, Lough \& Vioque, I96r), most of the glycerides of the diet being rapidly converted into free fatty acids. The hydrogenation of unsaturated fatty acids presumably takes place within the micro-organisms or on their surface (Williams, Gutierrez $\&$ Davis, 1963). Thus the newly formed stearic acid would be intimately associated with the organisms, probably being absorbed on the surface, and so be readily available for absorption lower down in the gut.

When in earlier work the linseed oil fatty acids were infused into the rumens of sheep, there was a reduction in the production of methane without any marked reduction in cellulolysis (Czerkawski et al. 1966b). This was not achieved in the present work mainly because of the choice of basal diet, which was suitable for ease and reproducibility of sampling, but was poor with regard to digestibility of cellulose. However, methanogenesis and cellulolysis were affected to different extents, methano- 
genesis being reduced by $30 \%$ and cellulolysis by $14 \%$. The digestion of crude protein was virtually unaltered and there was an improvement in the apparent digestibility of the non-lipid, non-cellulose dry matter of the ration. The ability of the rumen microflora to hydrogenate unsaturated fatty acids as their intake increased was not impaired.

Hydrogenation of unsaturated fatty acids in the rumen is at present one of the best known but least understood processes of rumen metabolism. It may simply be the outcome of the prevailing reducing conditions in the rumen, or it may be that there is some underlying biochemical requirement for such a process in the metabolism of certain rumen micro-organisms. Little is known about possible steps in the conversion of linolenic into stearic acid in the rumen. It appears that there is a tendency for the trans-octadecenoic acid, which does not occur in normal diets, to accumulate in the rumen (Czerkawski \& Blaxter, I965), and that linolenic acid is hydrogenated faster than either oleic or linoleic (Hoflund, Holmberg \& Sellmann, I956; Lough \& Garton, 1958; Shorland et al. 1957). Many studies of steps in hydrogenation of unsaturated $\mathrm{C}_{18}$ acids have been conducted in vitro (Polan, McNeill \& Tove, I964; Ward et al. 1964; Kepler, Hirons, NcNeill \& Tove, 1965), and a general scheme for hydrogenation of linolenic and possibly linoleic and oleic acids has emerged recently (Wilde \& Dawson, I966). It is still not certain whether such a scheme is applicable to conditions in vivo, such as reported here. The present results are not inconsistent with such a scheme except perhaps with respect to conjugation. Many in vitro studies indicate that the conjugated isomers of linoleic and linolenic acids might be intermediates in their biohydrogenation (Kepler, Hirons, McNeill \& Tove, I966) and yet there was no evidence of any significant bond migration during the present studies in vivo.

I am indebted to Dr K. L. Blaxter for helpful guidance in the early stages of the work. I also acknowledge the expert supervision of analytical work by Miss G. H. McG. Breckenbridge, and the help of other members of the Department of Nutrition with animals and with routine analyses.

\section{REFERENCES}

Armstrong, D. G., Blaxter, K. L. \& Graham, N. McC. (1957). Br. F. Nutr. I1, 392.

Crampton, E. W. \& Maynard, L. A. (1938). F. Nutr. 15, $3^{8} 3$.

Czerkawski, J. W. \& Blaxter, K. L. (I965). Biochem. F. 95, 25 c.

Czerkawski, J. W., Blaxter, K. L. \& Wainman, F. W. (I966a). Br. F. Nutr. 20, 349.

Czerkawski, J. W., Blaxter, K. L. \& Wainman, F. W. (r966b). Br. F. Nutr. 20, 485.

Folch, J., Lees, M. \& Stanley, G. H. S. (1957). F. biol. Chem. 226, 497.

Garton, G. A., Hobson, P. N. \& Lough, A. K. (1958). Nature, Lond. 182, I 5 I I.

Garton, G. A., Lough, A. K. \& Vioque, E. (1961). F. gen. Microbiol. 25, 215.

Hilditch, T. P. \& Williams, P. N. (I964). The Chemical Constitution of Natural Fats, p. 564. London: Chapman and Hall.

Hoflund, S., Holmberg, J. \& Sellmann, G. (1956). Cornell Vet. 46, 53.

Kates, M. (1964). F. Lipid Res. 5, 132.

Kepler, C. R., Hirons, K. P., McNeill, J. J. \& Tove, S. B. (1965). Fedn Proc. Fedn Am. Socs exp. Biol. 24, 290.

Kepler, C. R., Hirons, K. P., McNeill, J. J. \& Tove, S. B. (1966). F. biol. Chem. 24I, I350.

Lough, A. K. \& Garton, G. A. (1958). In Essential Fatty Acids: Proceedings of the Fourth International Conference on Biochemical Problems of Lipids, Oxford, I957, p. 97. [H.M. Sinclair, editor.] London: Butterworth's Scientific Publications. 
Polan, C. E., McNeill, J. J. \& Tove, S. B. (1964). F. Bact. 88, 1056.

Shorland, F. B., Weenik, R. O., Johns, A. T. \& McDonald, I. R. C. (1957). Biochem. F. $67,328$.

Ulyatt, M. J., Czerkawski, J. W. \& Blaxter, K. L. (1 966). Proc. Nutr. Soc. 25, xviii.

Wainman, F. W. \& Blaxter, K. L. (1958). Publs Eur. Ass. Anim. Prod. no. 8, p. 85.

Ward, P. F. V., Scott, T. W. \& Dawson, R. M. C. (I964). Biochem. F. 92, 60.

Wilde, P. F. \& Dawson, R. M. C. (r966). Biochem. F. 98, 469.

Williams, P. P., Gutierrez, J. \& Davis, R. E. (1963). Appl. Microbiol. II, 260. 